\title{
Electronic word of mouth in social media: the common characteristics of retweeted and favourited marketer-generated content posted on Twitter
}

\section{Hassan Alboqami, Wafi Al-Karaghouli, Yasser Baeshen, Ismail Erkan*, Chris Evans and Ahmad Ghoneim}

\author{
Brunel Business School, \\ Brunel University London, \\ UB8 3PH, UK \\ Fax: +44 (0)-1895232806 \\ Email: Hassan.Alboqami@brunel.ac.uk \\ Email: Wafi.Al-Karaghouli@brunel.ac.uk \\ Email: Yasser.Baeshen@brunel.ac.uk \\ Email: Ismail.Erkan@brunel.ac.uk \\ Email: Chris.Evans@brunel.ac.uk \\ Email: Ahmad.Ghoneim@brunel.ac.uk \\ *Corresponding author
}

\begin{abstract}
Marketers desire to utilise electronic word of mouth (eWOM) marketing on social media sites. However, not all online content generated by marketers has the same effect on consumers; some of them are effective while others are not. This paper aims to examine different characteristics of marketer-generated content (MGC) that of which one lead users to eWOM. Twitter was chosen as one of the leading social media sites and a content analysis approach was employed to identify the common characteristics of retweeted and favourited tweets. 2,780 tweets from six companies (Booking, Hostelworld, Hotels, Lastminute, Laterooms and Priceline) operating in the tourism sector are analysed. Results indicate that the posts which contain pictures, hyperlinks, product or service information, direct answers to customers and brand centrality are more likely to be retweeted and favourited by users. The findings present the main eWOM drivers for MGC in social media.
\end{abstract}

Keywords: electronic word of mouth; eWOM; social media; content analysis; marketer-generated content; MGC; Twitter; characteristics of tweets.

Reference to this paper should be made as follows: Alboqami, H., Al-Karaghouli, W., Baeshen, Y., Erkan, I., Evans, C. and Ghoneim, A. (2015) 'Electronic word of mouth in social media: the common characteristics of retweeted and favourited marketer-generated content posted on Twitter', Int. J. Internet Marketing and Advertising, Vol. 9, No. 4, pp.338-358.

Biographical notes: Hassan Alboqami is a PhD student in the Business School at Brunel University in London since 2013. He obtains his Master degree at Hertfordshire University in the UK 2011. In his $\mathrm{PhD}$, the research interests are electronic word of mouth (eWOM), social media and customer relationship management. 
Wafi Al-Karaghouli has BA in Statistics (Baghdad), MPhil in Statistics and Operations Research (London), PhD in IS Failures (Brunel), MBCS and MElite. He gained extensive experience with multinational companies. He has 12 years of industrial experience, one of which was a blue-chip, and 20 years of experience in higher education. A qualified practitioner in TQM and in project management methodology PRINCE2, his interests and research revolve around IT systems failures, knowledge management, and civil aviation. $\mathrm{He}$ has published extensively on the subject of IS failure. He contributed to the development of a knowledge management system at Merrill Lynch HSBC, BAA's fast-track check-in desks and the Iris Recognition Immigration System (iris) at Heathrow Airport.

Yasser Baeshen is a PhD student at Brunel University since 2013. He obtained his Master degree in Strategic Marketing at Wollongong University in Australia 2009. He is a Lecturer at King Abdulaziz University in Jeddah, Saudi Arabia. His research interests are electronic word of mouth (eWOM), social media and online consumer behaviour.

Ismail Erkan started his $\mathrm{PhD}$ at Brunel University in 2013. Before starting his $\mathrm{PhD}$, he completed his Master at Istanbul University in 2012. While he was doing his Master, he worked at Gebze Institute of Technology as a Research Assistant. His research interests are electronic word of mouth (eWOM), social media, customer engagement and purchase intention.

Chris Evans is a Senior Lecturer in the Brunel Business School at Brunel University. His research interests include interactivity, Web 2.0 and social media, multimedia learning technology, and the adoption of innovative learning technologies. He is chair of the annual eLearning 2.0 international conference on social media for learning.

Ahmad Ghoneim is a Lecturer of eBusiness and Information Systems at Brunel Business School. He is a member of the (ISEing) group - a research centre of excellence that supports a number of (EPSRC) funded networks and projects. Ahmad is the Programme Chair for the annual EMCIS conference and is on the editorial board of the TGPPP journal. He also co-edited special issues for $I J C E C$ and $E J I S$ journals.

All authors contributed equally and have been listed alphabetically.

\section{Introduction}

The developments in internet technologies provide new opportunities for companies to interact with their current and potential customers (Bickart and Schindler, 2001). Social media, as one of the milestones in the developing process of the internet, has also brought new possibilities to bridge marketers and consumers together via popular platforms such as Twitter, Facebook and YouTube. However, while social media facilitates the communication between companies and customers, it also increases the communication between customers about companies, which we call electronic word of mouth (eWOM) (Hennig-Thurau et al., 2004; Kozinets et al., 2010). 
Table 1 Summary of previous studies on MGC*

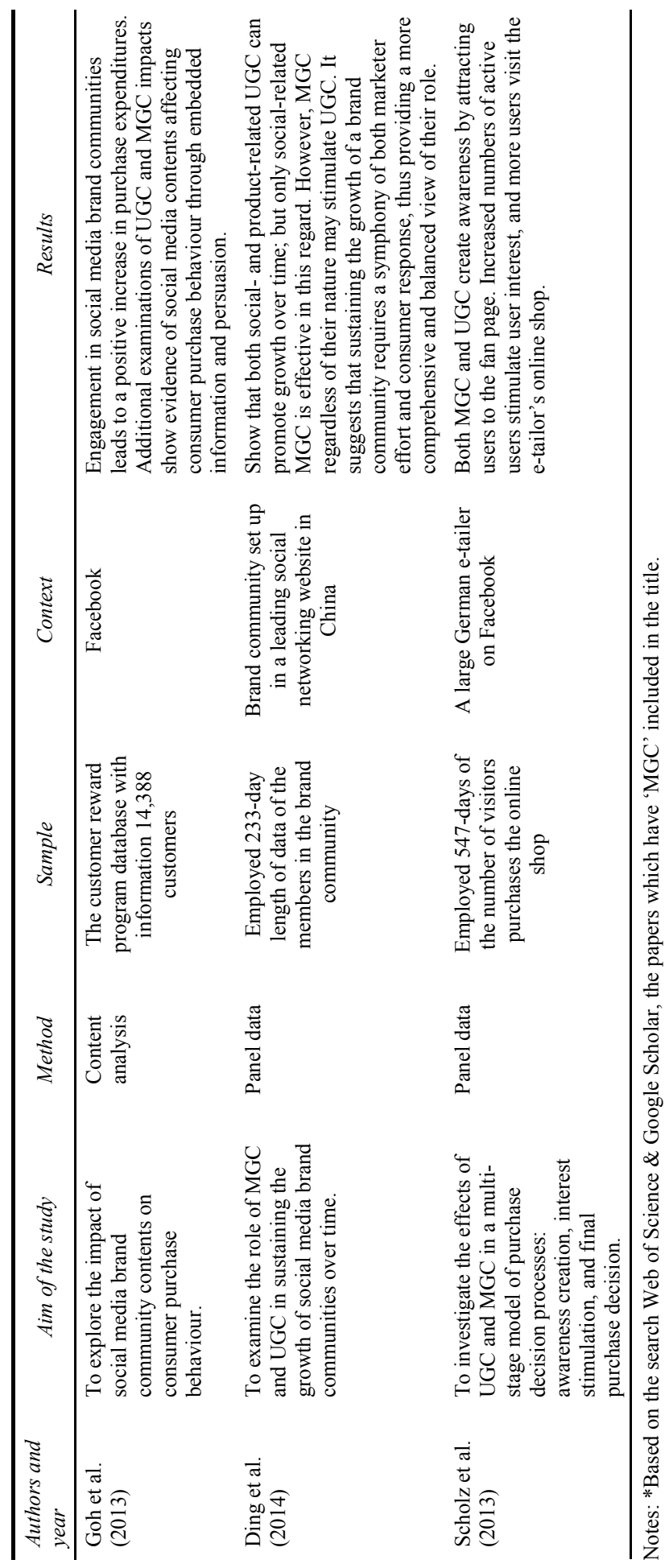


Table 1 Summary of previous studies on MGC*

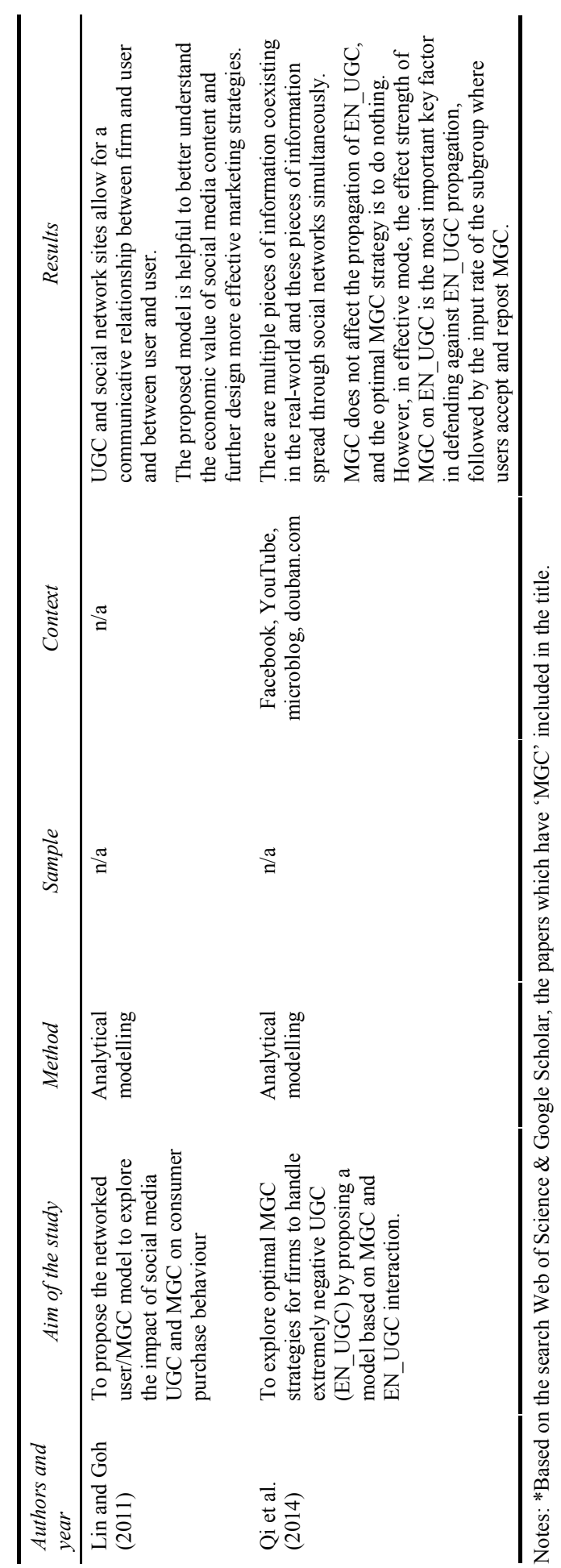


The effect of eWOM on consumers has long been known (Bickart and Schindler, 2001; Huang, 2010; Kumar and Benbasat, 2006; Park et al., 2007), but it has become more appropriate for consumer behaviour and exchanging information via the social media sites (Canhoto and Clark, 2013). The online conversations in social media naturally have a significant effect on consumers ' purchase intentions (Tsimonis and Dimitriadis, 2014; Wang et al., 2012) and brand awareness (Zadeh and Sharda, 2014), since they often contain brand names or refer to specific products or services (Wolny and Mueller, 2013).

Particularly in Twitter, almost one in five posts includes a specific brand name and one-fifth of these posts express positive or negative feelings about that brand (Jansen et al., 2009). When the number of tweets sent per day, which is 500 million (Twitter, 2015), is taken into account, the importance of eWOM conversations in Twitter can be seen more explicitly; an average 100 million tweets per day mention brands. For this reason, companies desire to interact with customers on Twitter by having official accounts; based on the latest statistics, $77 \%$ of Fortune 500 companies use Twitter actively and Twitter is the most used social media site among these companies (Barnes et al., 2013).

The content generated by marketers in Twitter can spread rapidly among users through eWOM (Jansen et al., 2009; Wolny and Mueller, 2013). However, while some content gets a high reaction, spreads rapidly and reaches more consumers, other content receives an inadequate reaction, or even no reaction, and cannot spread. Previous scholars (Berger and Milkman, 2012) who realised this difference have studied the issue, but social media was not the focus. Therefore, the aim of this research is to empirically investigate the characteristics of marketer-generated content (MGC) posted on social media and find those characteristics that make MGC more easily disseminated. In order to achieve this, we develop a conceptual framework that is based on the related literature and our observation on MGC.

This paper consider the characteristics of MGC in Twitter in four categories: contextual characteristics, informational characteristics, characteristics related to entertainment, and characteristics related to brand (De Vries et al., 2012; Smith et al., 2012; Suh et al. 2010). The findings provide directly applicable implications for marketers by highlighting some characteristics of MGC, and contribute to eWOM and social media literature. The remainder of the paper is as follows: first, concise review of the literature on eWOM, MGC and Twitter will be provided. Second, the developed framework and discuss of the methodology will be presented. Finally, the results of this study will highlight the discussion of findings and propose some opportunities for further research by considering the limitations of the study.

\section{Literature review}

\section{1 eWOM and $M G C$}

Word of mouth (WOM), which can be defined as communications among consumers about products and services of brands (Arndt, 1967), is recognised as one of the most influential marketing tools regarding consumer behaviour (Bone, 1995; Herr et al., 1991; Lee and Youn, 2009). However, it has gained a new aspect by the more widespread and frequent usage of the internet (Elwalda and Lu, 2014; Kim and Choi, 2012; King et al., 2014; Yayli and Bayram, 2012). Consumers have started to share their opinions and 
experiences about companies on the internet, known as eWOM (Hennig-Thurau et al., 2004). Marketers had always struggled regarding the negative side of WOM, which is difficult to control and influence (Godes and Mayzlin, 2004; Haywood, 1989); but today, with the advent of eWOM, while conversations among customers are still not completely under the control of marketers, there is the opportunity for them to explore the notions of customers and even lead the eWOM conversations by generating content.

EWOM offers several advantages for marketers. Through eWOM, the marketing message can be conveyed to huge number of people (Filieri and McLeay, 2014; Liu, 2006) in a short period of time (Huang et al., 2011; Hung and Li, 2007; King et al., 2014). It provides an opportunity to advertise, without necessitating the high budgets of traditional advertising methods. Marketers thus can improve brand awareness amongst consumers in a fast and cost-effective way (Litvin et al., 2008; Yang, 2013b). However, eWOM can also be detrimental to the image of companies when the communication is instigated by unhappy customers (Ferguson and Johnston, 2011); eWOM has also cons as well as pros. EWOM conversations are able to start with either MGC or user-generated content (UGC) (Bickart and Schindler, 2001).

So far, research studies in this field has mostly focused on UGC (Christodoulides et al., 2012; Presi et al., 2014; Smith et al., 2012), while some studies compare UGC and MGC as a focal point (Goh et al., 2013; Lim et al., 2012) (see Table 1). However, notwithstanding these few studies, MGC has not yet been separately examined in detail. Therefore one of the aims of this study is to expand the related literature, by focusing on MGC.

MGC publishes content on the internet, which is created by marketers, on behalf of their companies, in order to interact with customers (Goh et al., 2013). Marketers can control the context of information just as in advertising (van den Bergh et al., 2011) and introduce their brands, products and services. Users can respond to MGC by replying or sharing the content with each others. Thus, any MGC may have the potential to reach millions of users on the internet through eWOM (Sigala et al., 2012). Therefore the content of the message, target of the message and its location must be evaluated by marketers in detail (Barnes and Hunt, 2000; Kotler and Armstrong, 2013). Recently, social media has been considered as one of the most appropriate and powerful platforms for MGC (Canhoto and Clark, 2013), this is due to bringing large numbers of users together (Belk and Llamas, 2013). However, while this is an opportunity for marketers to initiate eWOM conversations among their targeted customers, not all MGC has the same impact on consumers; some content achieve a high response while others do not (De Vries et al., 2012). For this reason, creating accurate content is surely important to gain a positive customer response (Reichelt et al., 2014) and thus, this study particularly focus on the characteristics of MGC that make it accurate and lead users to use eWOM in social media.

\subsection{Social media sites and Twitter}

Social media sites are described as web-based services that allow people to build and expand their friend networks by creating personal profiles (Boyd and Ellison, 2007). These websites have spread dramatically throughout the world and due to this growing interest and usage, the number and type of social media sites have also increased. Latest statistics show that three social media sites, namely Facebook, YouTube and Twitter, are 
among the top ten most visited websites in the world (Alexa, 2015). Therefore these websites draw the attention of many marketers as well as researchers. Marketers view these websites as an opportunity to interact with customers (Gangadharbatla et al., 2012; Michaelidou et al., 2011) because the number of people who use social media as a part of their daily life is noticeably high and these people share their experiences, preferences and opinions regarding the products or services of brands on the social media. Particularly Twitter has 288 million active users (Twitter, 2015) and almost $20 \%$ of tweets mention brands (Jansen et al., 2009), which provides a great opportunity for marketers to track and learn from customers' experience about the company.

On the other hand, according to Jansen et al. (2009) Twitter is also considered as the most popular micro-blogging platform which allows users to post within a 140 character only. Users can also post simply by retweeting others' tweets and this characteristic of Twitter, of being short and convenient, encourages users to post more often (Sakaki et al., 2010). However, this does not mean that Twitter only allows text-oriented messages; users are able to enrich their posts through pictures, videos, and website links. In addition, most of the tweets can be seen publicly, without logging into the website, and these aforementioned features make Twitter an appropriate platform for eWOM. Hence, information about companies has the potential to spread easily among a large number of Twitter users thanks to these features. Creating an official account on a website and interacting with customers is important for marketers. Through these official accounts, marketers can provide customers with information or news relevant to their brands, products, services or promotions and lead customers to tweet about the company.

Users may either mention the companies in their posts or retweet (i.e., forward the message) the tweets generated by marketers. In both ways, the information about the company can spread and shared among users through eWOM. Every tweet has a retweet (RT) number on it which shows how many times it has been shared by users, and this RT number is accepted as one of the biggest indicators of eWOM in Twitter (Hoffman and Fodor, 2010; Wolny and Mueller, 2013). In addition, all tweets have favourite (FAV) numbers on them and this information indicates the number of users who have saved the tweets as one of their favourite tweets. Although it is not as strong indicator as the RT number, hence it is not considered as indicator of eWOM by academics so far. FAV number can also be signs of eWOM in Twitter, because when a user marks the tweets as their favourite tweets, others are able to see them in the user's profile. Therefore, in this study, FAV numbers is accepted as a tool for measuring eWOM.

Consequently, marketers generate content in order to interact with their current and potential customers in Twitter because of several mentioned reasons. They can spread MGC through eWOM and follow the results by tracking the RT and FAV numbers. However different tweets have different RT and FAV rates and this shows they do not all get the same reactions from users. While some tweets get a big response and spread rapidly through eWOM, some others get a small response, or even no response, and do not spread. We thus understand that there should be some characteristics of tweets that play important role for getting a greater reaction. Then, what are the key characteristics of tweets that enable MGC to spread more rapidly and widely through being retweeted and favourited? The answer to this question is of great importance for both marketers who want to promote their brands and academics who want to study Twitter and eWOM. 


\subsection{Characteristics of marketer-generated tweets that lead users to eWOM}

In order to identify the characteristics of tweets, first, the literature has been critically reviewed in the context of stimulating eWOM (Boyd et al., 2010; De Vries et al., 2012; Hennig-Thurau et al., 2004; Smith et al., 2012 and etc.). Second the marketer-generated tweets (MGT) have been examined. Finally, all extracted characteristics were categorised into four dimensions (see Figure 1). These dimensions will be discussed in detail in the following section.

Figure 1 Characteristics of MGC posted on Twitter

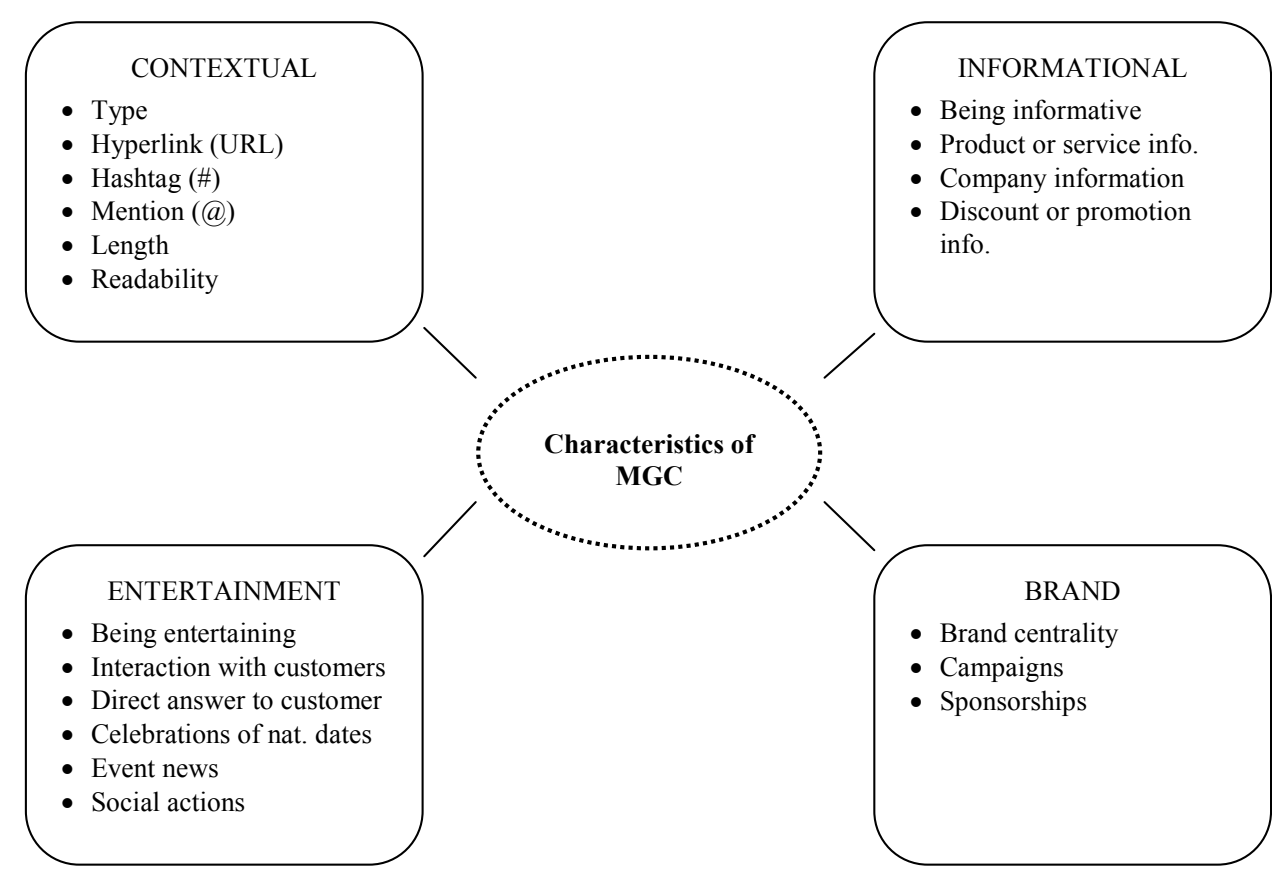

\subsubsection{Contextual characteristics}

Tweets can include pictures, videos or they can be text-only messages. Due to the natural structure of tweets, it is easy to distinguish quickly, especially when they include pictures or videos. For example, if users, who are looking at a Twitter page, have very little time, they will more likely see those tweets that contain pictures or videos. This may increase the possibility of sharing the content (Rogers, 2014). In addition, having a hyperlink, hashtag (\#) or mention (@) signs are other contextual characteristics of tweets (Boyd et al., 2010; Suh et al., 2010). According to Boyd et al. (2010), more than half of retweets contain a hyperlink, almost one-fifth have a hashtag and nearly one-tenth have a mention inside.

Finally, the length and readability of tweets are the last two contextual features in this study that may affect the distribution of a message. The possibility of sharing can be low when the tweet already has 140 characters and does not leave extra space to a person who wants share it. These tweets do not give the reader the chance to add their own opinions 
about the content. Moreover, if the tweet is not easy to understand, this may naturally lead readers not to share it.

\subsubsection{Informational characteristics}

Having a product, service or any information is one of the apparent features of MGT. In fact, if the content is functional (Lovett et al., 2013) and helps to solve users' problems it can spread quickly via WOM (Yen et al., 2011). This is because people enjoy helping others through sharing their knowledge in online platforms (Cheung and Lee, 2012; Hennig-Thurau et al., 2004). In addition, if the tweets contain information about the company this may invoke emotions, and customers might like to share the content with their friends or acquaintances (Berger and Milkman, 2012; Lovett et al., 2013; Peters and Kashima, 2007).

Giving discount or promotional information on a tweet is another tool to attract users to share. These types of information increase the willingness of people to engage with the content and WOM advertising (Nusair et al., 2010). Consumers perceive the discount or promotional information of companies as a reward (Yen et al., 2011) and an opportunity for themselves (Gruen et al., 2006).

\subsubsection{Characteristics related to entertainment}

Entertainment is a great motivational instrument for users to participate in eWOM; tweets that contain fun and a sense of humour draw users' attention easily (Bronner and de Hoog, 2010). Twitter provides a valuable chance for marketers to interact with their current and potential customers, as many companies do. Asking eye catching questions, celebrating national dates, announcing events and supporting social actions or replying to users` questions are some examples of interaction methods (Smith et al., 2012) that might increase the possibility of eWOM (De Vries et al., 2012).

\subsubsection{Characteristics related to brands}

Brand centrality refers to role of the brands in MGT and explains whether it is in focus of the content or not (Smith et al., 2012). Introducing more than one topic in a single tweet is not easy due to the 140-character limit, so brand centrality might change according to content (Jansen et al., 2009).

Lastly, containing sponsorship and campaign news are two distinguished characteristics of MGT noticed during the observational part of this study. Companies try to inform and attract people by announcing their sponsorships for events, charities or teams and their online and offline campaigns for customers. Both campaigns for online channels such as social media and offline ones such as in-store campaigns are able to be announced in Twitter via tweets. Particularly, campaign news might encourage people to share the content and initiate the eWOM activity among users.

These characteristics all have the potential to make MGT more dispersible. Therefore, in this study, they are all tested separately in order to find whether they are effective on MGT or not. We identified the common characteristics of retweeted and favourited MGT by undertaking an empirical study, which is presented in the following section. 


\section{Methodology}

A content analysis was conducted with 2,780 tweets generated by marketers. Content analysis is an observational method that scientifically compares the content of recorded communications (Kolbe and Burnett, 1991). It has been used by many researchers to analyse both online and offline content (Roznowski, 2003; Smith et al., 2012). For this research, content analysis offers an analytic way to compare the content of a large sample of MGT. The study has been conducted based on the following conceptual framework (see Figure 2).

Figure 2 Conceptual framework.

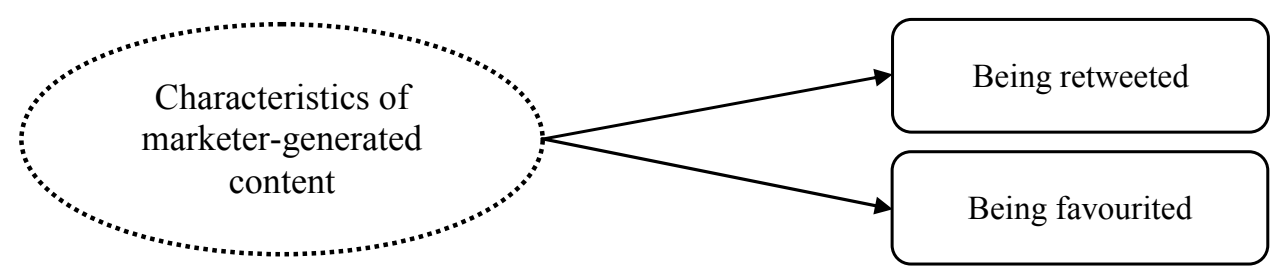

\subsection{Sampling}

Tweets were selected from the official Twitter accounts of six pure-play e-commerce companies operating in the tourism sector: Booking.com, Hostelworld.com, Hotels.com, Lastminute.com, Laterooms.com and Priceline.com. The reason for choosing pure-play ecommerce companies is that they carry on their business on the internet and are not as active as other companies in the offline world (e.g., they do not have stores). The tourism sector was chosen to avoid a brand lovers effect, which leads people to like and share every post by companies without considering their content (e.g., the automotive sector). This effect was noticed during our observation on MGT. Finally, all tweets written by these companies during the period of 1 March 2014 and 15 June 2014 were examined independently; the research period was decided with respect to the beginning of the tourism season.

\subsection{Coding}

Operational coding instructions were developed for all dependent and independent variables prior to starting coding. Table 2 shows these instructions for each variable. A pre-test was undertaken among the coders, who are researchers in this study, in order to test the relevance of the variables and prevent the occurrence of different comments for similar circumstances. The data were then coded manually; binary coding was used, where 1 indicated the presence of a characteristic and 0 indicated its absence (see Table 2) (Smith et al., 2012; Swani et al., 2014). Discrepancies in coding were resolved by a researcher of the team. 
Table 2 Coding Instructions.

\begin{tabular}{|c|c|c|c|}
\hline \multicolumn{2}{|c|}{ Variables } & \multicolumn{2}{|l|}{ Coding } \\
\hline \multicolumn{4}{|c|}{ Dependent variables: } \\
\hline 1 & Being retweeted & If the tweet is retweeted: coded as 1 & - If not: 0 \\
\hline 2 & Being favourited & If the tweet is favourited: 1 & - If not: 0 \\
\hline \multicolumn{4}{|c|}{ Independent variables: } \\
\hline 1 & Picture & If there is a picture in the tweet: coded as 1 & - If not: 0 \\
\hline 2 & Video & If there is a video in the tweet: 1 & - If not: 0 \\
\hline 3 & Only text & If there is no picture or video in the tweet: & - If yes: 0 \\
\hline 4 & Hyperlink & If there is a link in the tweet: 1 & - If not: 0 \\
\hline 5 & Hashtag & If there is a '\#' in the tweet: 1 & - If not: 0 \\
\hline 6 & Mention & If there is a '@' in the tweet: 1 & - If not: 0 \\
\hline 7 & Length & If it is longer than 100 characters: 1 & - If not: 0 \\
\hline 8 & Readability & If the tweet is clear and easy to understand: & - If not: 0 \\
\hline 9 & Being informative & If there is ANY information: 1 & - If not: 0 \\
\hline 10 & Product or service info. & If there is this information: 1 & - If not: 0 \\
\hline 11 & Company information & $\begin{array}{c}\text { If there is this information: } 1 \text { (e.g., } \\
\text { rewards) }\end{array}$ & - If not: 0 \\
\hline 12 & Discount or promotion info. & If there is this information: 1 & - If not: 0 \\
\hline 13 & Being entertaining & If there is something entertaining: 1 & - If not: 0 \\
\hline 14 & Interaction with customers & $\begin{array}{c}\text { If there is customer interaction: } 1 \text { (e.g., } \\
\text { asks questions) }\end{array}$ & - If not: 0 \\
\hline 15 & Direct answer to customer & $\begin{array}{l}\text { If there is a direct answer to ONE } \\
\text { customer: } 1\end{array}$ & - If not: 0 \\
\hline 16 & Event news & If there is event news: 1 & - If not: 0 \\
\hline 17 & Social actions & $\begin{array}{c}\text { If there is a social action: } 1 \text { (e.g., protecting } \\
\text { animal rights...) }\end{array}$ & - If not: 0 \\
\hline 18 & Celebrations of nat. dates & If there is a national date: 1 & - If not: 0 \\
\hline 19 & Brand centrality & If the brand is in the focus of tweet: 1 & - If not: 0 \\
\hline 20 & Campaigns & If there is news about a campaign: 1 & - If not: 0 \\
\hline 21 & Sponsorships & If there is news about a sponsorship: 1 & - If not: 0 \\
\hline
\end{tabular}

\section{Results and analysis}

The coding frequencies show that all companies have a high number of RT and FAV rates (see Table 3). It also shows how characteristics of MGC differentiate across the six companies; as an example, some companies prefer to use pictures and videos to post while some others prefer text-only posts. 
Table 3 Coding frequencies

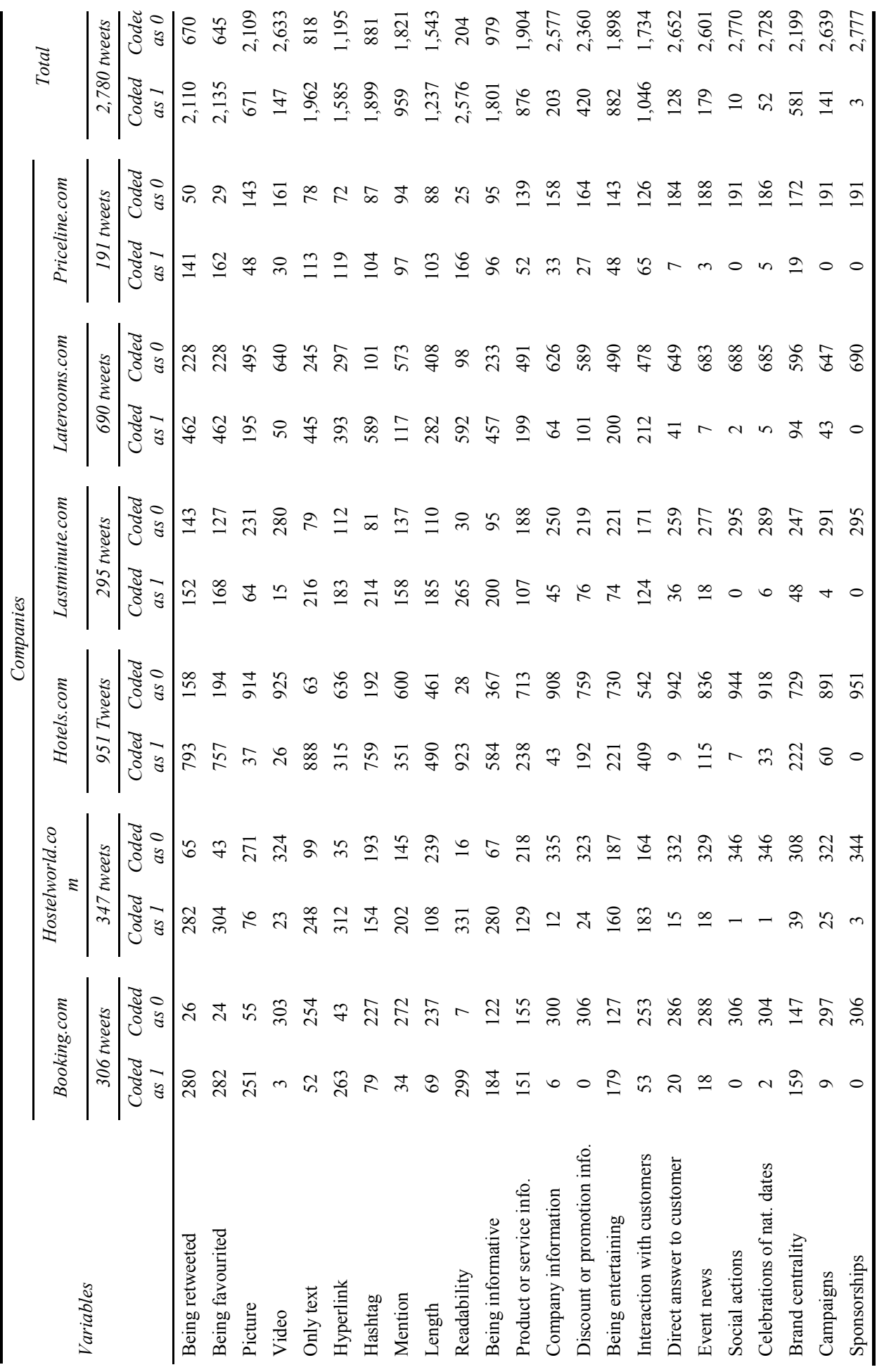


In order to understand the factors that affect customers to retweet and favourite marketers' tweets, logistic regression was employed. Logistic regression is a form of regression where the independent factors are categorical or continuous, and the outcome is binary (Akinci et al., 2007). In logistic regression models, many factors influencing dependent variables may be included (Chen et al., 2008). Logistic regression has recently gained more popularity within marketing research. Akinci et al. (2007) contend that as logistic regression generates a better model fit and findings; it is a very useful technique for modelling marketing problems.

Table 4 Logistic regression results for the retweet model

\begin{tabular}{lcccc}
\hline & $B$ & $S E$ & Wald & Sig. \\
\hline Picture & 1.134 & 0.250 & 20.504 & $\mathbf{0 . 0 0 0}$ \\
Video & -0.266 & 0.280 & 0.900 & 0.343 \\
Only text & -0.081 & 0.231 & 0.122 & 0.727 \\
Hyperlink & 0.268 & 0.103 & 6.797 & $\mathbf{0 . 0 0 9}$ \\
Hashtag & 0.020 & 0.111 & 0.031 & 0.860 \\
Mention & -0.299 & 0.102 & 8.554 & $\mathbf{0 . 0 0 3}$ \\
Length & -0.031 & 0.102 & 0.091 & 0.763 \\
Readability & 0.261 & 0.176 & 2.197 & 0.138 \\
Being informative & -0.018 & 0.110 & 0.028 & 0.868 \\
Product or service info. & -0.255 & 0.128 & 3.985 & $\mathbf{0 . 0 4 6}$ \\
company information & 0.310 & 0.193 & 2.594 & 0.107 \\
Discount and promotion info. & -0.130 & 0.147 & 0.787 & 0.375 \\
Being entertaining & 0.167 & 0.116 & 2.046 & 0.153 \\
Interaction with customers & 0.082 & 0.102 & 0.649 & 0.421 \\
Direct answer to customer & -1.427 & 0.208 & 47.125 & $\mathbf{0 . 0 0 0}$ \\
Event news & -0.067 & 0.206 & 0.105 & 0.746 \\
Social actions & -0.390 & 0.732 & 0.284 & 0.594 \\
Celebrations of nat. dates & 1.655 & 0.604 & 7.510 & $\mathbf{0 . 0 0 6}$ \\
Brand centrality & 0.528 & 0.152 & 12.079 & $\mathbf{0 . 0 0 1}$ \\
Campaigns & 0.013 & 0.260 & 0.002 & 0.961 \\
Sponsorships & -1.083 & 1.295 & 0.699 & 0.403 \\
Constant & 0.742 & 0.306 & 5.877 & 0.015 \\
\hline Notes: Bold figur: signifin & & & &
\end{tabular}

Notes: Bold figures: significant variables, $p$-value $<0.05$.

The empirical part of the study is divided into two parts according to our dependent variables; both retweet and favourite model are tested with independent variables. The results of the Hosmer and Lemeshow test show that both retweet $(\chi 2=9.943, \mathrm{df}=8, p=$ $0.269)$ and favourite model $\left(\chi^{2}=9.413 \mathrm{df}=8, p=0.309\right)$ adequately fit the data, because the $p$-values of the tests are greater than 0.05 (Hosmer et al., 2013). Using 'enter method for logistic regression, the results for the retweet model illustrate that there are seven predictors that contribute significantly $(p<0.05)$ to the ability of the retweet model, namely - picture $(\mathrm{B}=1.134, p<0.000)$, hyperlink $(\mathrm{B}=0.268, p<0.009)$, mention $(\mathrm{B}=-0.299, p<0.003)$, product or service information $(\mathrm{B}=-0.255, p<0.046)$ 
direct answer to customer $(\mathrm{B}=-1.427, p<0.000)$, celebrations of national dates $(\mathrm{B}=$ $1.655, p<0.006)$, and brand centrality $(\mathrm{B}=0.528, p<0.001)$ (see Table 4$)$. The results suggest that these characteristics have a significant impact on customers' retweet decisions. The MGT that contain such characteristics are spread among Twitter users through retweeting. However, contrary to expectations, being entertaining ( $p=0.153)$, discount and promotion information $(p=0.375)$ and campaigns $(p=0.961)$ have no significant effect on consumers` retweet decisions.

On the other hand, the favourite model findings demonstrate that there are ten predictors that contribute significantly $(p<0.05)$ to the ability of the favourite model, namely - picture $(\mathrm{B}=1.856, p<0.000)$, hyperlink $(\mathrm{B}=0.209, p<0.046)$, hashtag $(\mathrm{B}=$ -0.472 ,

$p<0.000)$, readability $(\mathrm{B}=0.423, p<0.015)$, product or service information $(\mathrm{B}=$ $-0.369, p<0.005)$, being entertaining $(\mathrm{B}=0.288, p<0.022)$, interaction with customers $(\mathrm{B}=0.252, p<0.016)$, direct answer to customer $(\mathrm{B}=-1.162, p<0.000)$, brand centrality $(\mathrm{B}=0.472, p<0.003)$, campaigns $(\mathrm{B}=0.649, p<0.028)$ (see Table 5$)$.

Table 5 Logistic regression results for the favourite model

\begin{tabular}{lcccc}
\hline & $B$ & $S E$ & Wald & Sig. \\
\hline Picture & 1.856 & 0.297 & 38.977 & $\mathbf{0 . 0 0 0}$ \\
Video & 0.134 & 0.353 & 0.145 & 0.703 \\
Only text & -0.165 & 0.248 & 0.440 & 0.507 \\
Hyperlink & 0.209 & 0.105 & 3.964 & $\mathbf{0 . 0 4 6}$ \\
Hashtag & -0.472 & 0.121 & 15.210 & $\mathbf{0 . 0 0 0}$ \\
Mention & 0.004 & 0.105 & 0.001 & 0.973 \\
Length & 0.146 & 0.105 & 1.941 & 0.164 \\
Readability & 0.423 & 0.175 & 5.862 & $\mathbf{0 . 0 1 5}$ \\
Being informative & -0.050 & 0.113 & 0.193 & 0.660 \\
Product or service info. & -0.369 & 0.131 & 7.897 & $\mathbf{0 . 0 0 5}$ \\
Company information & -0.029 & 0.183 & 0.025 & 0.875 \\
Discount and promotion info. & -0.102 & 0.149 & 0.469 & 0.493 \\
Being entertaining & 0.288 & 0.126 & 5.254 & $\mathbf{0 . 0 2 2}$ \\
Interaction with customers & 0.252 & 0.104 & 5.837 & $\mathbf{0 . 0 1 6}$ \\
Direct answer to customer & -1.162 & 0.209 & 30.847 & $\mathbf{0 . 0 0 0}$ \\
Event news & -0.215 & 0.209 & 1.058 & 0.304 \\
Social actions & -0.729 & 0.687 & 1.125 & 0.289 \\
Celebrations of nat. dates & -0.578 & 0.324 & 3.194 & 0.074 \\
Brand centrality & 0.472 & 0.160 & 8.706 & $\mathbf{0 . 0 0 3}$ \\
Campaigns & 0.649 & 0.296 & 4.807 & $\mathbf{0 . 0 2 8}$ \\
Sponsorships & -2.629 & 1.462 & 3.235 & 0.072 \\
Constant & 0.833 & 0.324 & 6.608 & 0.010 \\
\hline Note Bold figurs &,$p-v a v<0.05 .69$ \\
\hline
\end{tabular}

Note: Bold figures: significant variables, $p$-value $<0.05$.

According to our results, these ten characteristics are the main drivers for customers to favourite companies` tweets. In other words, the MGT that include such characteristics 
are spread among Twitter users through favouriting. Furthermore, both retweet and favourite models have some common results; five characteristics are significant in both models (picture, hyperlink, product or service information, direct answer to customer, brand centrality), while nine of them are not significant (video, only text, length, being informative, company information, discount and promotion information, event news, social actions, sponsorships) (see Table 6).

Table 6 Comparison of the results of retweet and favourite models

\begin{tabular}{|c|c|c|}
\hline & Retweet model & Favourite model \\
\hline Picture & $\checkmark$ & $\checkmark$ \\
\hline Video & $\mathrm{x}$ & $\mathrm{x}$ \\
\hline Only text & $\mathrm{x}$ & $\mathrm{x}$ \\
\hline Hyperlink & $\checkmark$ & $\checkmark$ \\
\hline Hashtag & $\mathrm{x}$ & $\checkmark$ \\
\hline Mention & $\checkmark$ & $\mathrm{x}$ \\
\hline Length & $\mathrm{x}$ & $\mathrm{x}$ \\
\hline Readability & $\mathrm{x}$ & $\checkmark$ \\
\hline Being informative & $\mathrm{x}$ & $\mathrm{x}$ \\
\hline Product or service info. & $\checkmark$ & $\checkmark$ \\
\hline Company information & $\mathrm{x}$ & $\mathrm{x}$ \\
\hline Discount and promotion info. & $\mathrm{x}$ & $\mathrm{x}$ \\
\hline Being entertaining & $\mathrm{x}$ & $\checkmark$ \\
\hline Interaction with customers & $\mathrm{x}$ & $\checkmark$ \\
\hline Direct answer to customer & $\checkmark$ & $\checkmark$ \\
\hline Event news & $\mathrm{x}$ & $\mathrm{x}$ \\
\hline Social actions & $\mathrm{X}$ & $\mathrm{x}$ \\
\hline Celebrations of nat. dates & $\checkmark$ & $\mathrm{x}$ \\
\hline Brand centrality & $\checkmark$ & $\checkmark$ \\
\hline Campaigns & $\mathrm{x}$ & $\checkmark$ \\
\hline Sponsorships & $\mathrm{x}$ & $\mathrm{x}$ \\
\hline
\end{tabular}

Notes: $\checkmark$ refers to significance; $x$ refers to insignificance.

\section{Discussion and conclusions}

This study set out with the aim in identifying the characteristics of MGC which lead users to the use of eWOM in social media. The study's aim was accomplished by analysing the posts of six companies (Booking.com, Hostelworld.com, Hotels.com, Lastminute.com, Laterooms.com and Priceline.com) in the tourism industry in the social media site Twitter. The study's findings indicate that pictures, hyperlinks, product or service information, direct answers to customers, and brand centrality are the main attributes that companies' posts should contain to be circulated among consumers. Understanding such attributes is of importance for both theoretical and practical practices. The present study 
brings new insights to the antecedents of eWOM and the use of social media for marketing purposes.

Our findings show that, in terms of contextual characteristics, pictures, hyperlinks, hashtags and mentions are the most important drivers for eWOM. Firstly, both retweet and favourite models support that the use of pictures significantly affects customers to engage in eWOM. This suggests that tweets that contain pictures are more likely to be retweeted and favourited by customers. The observed increase in the retweet and favourite rates resulting from pictures could be attributed to the recognition element. Attention-receiving ability is an important component of any marketing activity; pictures have such ability to draw people's attention to posts (MacKenzie, 1986). Secondly, containing a hyperlink was found to affect a customer's intention to adopt eWOM. Tweets that have a hyperlink seem to gain customers' attention more than those that do not. Finally, our results show that eWOM adoption is impacted by hashtags, mentions and readability; signifying that a company receives more attention when it uses hashtags or mentions and when the posts are easy to read. These results correspond to previous research; although the extant researches generalise their results on all tweets, instead of focusing on MGC, previous researches have also identified that having pictures, links and hashtags are important in order to be retweeted (Boyd et al., 2010; Suh et al., 2010; Zarrella, 2009). Other contextual characteristics, such as having video, being text only and the tweet length, on the other hand, have no significant effect on eWOM, since both retweet and favourite models found no significant influence for these characteristics.

The findings also show that information about the products or services significantly affects consumers' intention to adopt eWOM. Both the retweet and favourite models confirm that among the informational characteristics, product or service information is the only attribute that significantly affects retweet and favourite rates. This result suggests that customers pay more attention to posts and tweets that provide information about products or services. A possible explanation for this result may be that customers perceive such tweets to be useful since they might provide, for example, guidelines, tips, or instructions. This is in line with previous researches that reported that eWOM usefulness plays a significant role in adopting eWOM information (Liang et al., 2013; Yang, 2013a).

Contrary to expectations, this study did not find a significant effect of discount and promotion information on the adoption of eWOM information. It appears that consumers are not affected by this kind of information. Nevertheless, the findings of the current study do not support the previous research, which argues that eWOM adoption is influenced by discount and promotion information (Nusair et al., 2010). A possible explanation for this result is that price discount may be associated with the perception of low quality products or services (Grewal et al., 1998). As a consequence of investigating eWOM adoption in a tourism context, such perception of low quality might have a greater impact on customers, and therefore, may not influence their information adoption behaviour.

With regard to entertainment characteristics, the present study shows that being entertaining, interaction with customers, direct answers to customers and celebrations of national dates have a significant effect on eWOM adoption. Particularly, customers tend to engage more in eWOM when a company gives direct answers to them on Twitter. This seems to be a key driver for a customer's engagement in eWOM as it was supported by both the retweet and favourite models. In addition, the result regarding being entertaining supports previous researches that reported the engagement of online users is greatly 
affected by enjoyment (Cheung and Lee, 2012; Okazaki, 2009; Schindler and Bickart, 2005). Moreover, this study reveals that customers are interested in companies' posts and tweets that celebrate national dates.

Finally, drawing on brand characteristics, this study indicates a significant impact of brand centrality and campaigns on eWOM adoption. Both the retweet and favourite models disclose that customers' adoption of eWOM is significantly affected by brand-focused posts. Furthermore, posting about campaigns was also found to affect eWOM adoption, but this result was only supported by the favourite model. Lastly, both the retweet and favourite models found no significant relationship between announcing sponsorships of companies and eWOM adoption; customers do not demonstrate any reaction to these posts, neither retweeting nor favouriting.

\section{Academic and managerial implications}

The paper provides considerable amount of contributions toward the literature of eWOM. First, the paper provides a sufficient previous research that can be used in further studies to develop better understanding for the models describing effective MGC. Second, the paper provides an up-to-date empirical and theoretical literature review on eWOM and its impact on marketing which can be useful for further studies. On the other hand, in terms of practicality, the paper highlighted many aspects and features of online posting which are critical marketing elements that companies need in today's online advertising world. Results can help managers and marketers to improve marketing strategies through better understanding of customers' preferences.

\section{Limitations and suggestions for future research}

Although the findings of this study have provided a significant contribution on MGC and new insights on eWOM in social media, the results should be considered in the light of the Twitter context. Further studies could apply this study to other social media sites to extend and clarify the picture of MGC in social media. Additionally, the data were gathered from six pure-play e-commerce companies in the tourism sector; in future research, the other sectors can be examined, or the posts of bricks and mortar companies could be tested to see if the results vary.

Lastly, the aim of this study was to identify the common characteristics of retweeted and favourited MGC posted on Twitter; therefore the dependent variables were coded by putting either zero or one, which means the tweet is retweeted or not and favourited or not. For further studies, tweets or posts could be tested by considering the level of response through coding the tweets with their exact RT and FAV numbers. Nevertheless, this study provides useful implications for marketers and presents new possibilities for researchers.

\section{Acknowledgements}

We thank PhD Researchers Abdulaziz Elwalda and Mohammed Alsaggaf for their valuable comments and insights on this article. 


\section{References}

Akinci, S., Kaynak, E., Atilgan, E. and Aksoy, S. (2007) 'Where does the logistic regression analysis stand in marketing literature? A comparison of the market positioning of prominent marketing journals', European Journal of Marketing, Vol. 41, Nos. 5/6, pp.537-567.

Alexa (2015) The Top 500 Sites on the Web [online] http://www.alexa.com/topsites (accessed 16 April 2015).

Arndt, J. (1967) 'Role of product-related conversations in the diffusion of a new product', Journal of Marketing Research, Vol. 4, No. 3, pp.291-295.

Barnes, N.G., Lescault, A. and Wright, S. (2013) Fortune 500 are Bullish on Social Media: Big Companies Get Excited About Google, Instagram, Foursquare and Pinterest [online] University of Massachusetts Dartmouth Center for Marketing Research [online] https://www.umassd.edu/media/umassdartmouth/cmr/studiesandresearch/2013_Fortun e_500.pdf (accessed 16 April 2015).

Barnes, S. and Hunt, B. (2000) E-Commerce and V-Business: Business Models for Global Success, Butterworth-Heinemann, Great Britain.

Belk, R.W. and Llamas, R. (Eds.) (2013) The Routledge Companion to Digital Consumption, Routledge, New York.

Berger, J. and Milkman, K.L. (2012) 'What makes online content viral?', Journal of Marketing Research, Vol. 49, No. 2, pp.192-205.

Bickart, B. and Schindler, R.M. (2001) 'Internet forums as influential sources of consumer information', Journal of Interactive Marketing, Vol. 15, No. 3, pp.31-40.

Bone, P.F. (1995) 'Word-of-mouth effects on short-term and long-term product judgments', Journal of Business Research, Vol. 32, No. 3, pp.213-223.

Boyd, D., Golder, S. and Lotan, G. (2010) 'Tweet, tweet, retweet: conversational aspects of retweeting on Twitter', System Sciences (HICSS) 43rd Hawaii International Conference, IEEE, pp.1-10.

Boyd, D.M. and Ellison, N.B. (2007) 'Social network sites: definition, history, and scholarship', Journal of Computer-Mediated Communication, Vol. 13, No. 1, pp.210-230.

Bronner, F. and de Hoog, R. (2010) 'Vacationers and eWOM: who posts, and why, where, and what?', Journal of Travel Research, Vol. 50, No. 1, pp.15-26.

Canhoto, A.I. and Clark, M. (2013) 'Customer service 140 characters at a time: the users' perspective', Journal of Marketing Management, Vol. 29, Nos. 5-6, pp.522-544.

Chen, C., Yang, H.P., Chen, C. and Chen, T. (2008) 'Diagnosing and revising logistic regression models: effect on internal solitary wave propagation', Engineering Computations, Vol. 25 , No. 2, pp.121-139.

Cheung, C.M. and Lee, M.K. (2012) 'What drives consumers to spread electronic word of mouth in online consumer-opinion platforms', Decision Support Systems, Vol. 53, No. 1, pp.218-225.

Christodoulides, G., Jevons, C. and Bonhomme, J. (2012) 'Memo to marketers: quantitative evidence for change: how user-generated content really affects brands?', Journal of Advertising Research, Vol. 52, No. 1, pp.53-64.

De Vries, L., Gensler, S. and Leeflang, P.S. (2012) 'Popularity of brand posts on brand fan pages: an investigation of the effects of social media marketing', Journal of Interactive Marketing, Vol. 26, No. 2, pp.83-91.

Ding, Y., Phang, C.W., Lu, X., Tan, C.H. and Sutanto, J. (2014) 'The role of marketer-and user-generated content in sustaining the growth of a social media brand community', 47th Hawaii International Conference System Sciences (HICSS), IEEE, pp.1785-1792.

Elwalda, A. and Lu, K. (2014) 'The influence of online customer reviews on purchase intention: the role of non-numerical factors', Proceedings of the LCBR European Marketing Conference 2014. 
Ferguson, J.L. and Johnston, W.J. (2011) 'Customer response to dissatisfaction: a synthesis of literature and conceptual framework', Industrial Marketing Management, Vol. 40, No. 1, pp.118-127.

Filieri, R. and McLeay, F. (2014) 'E-WOM and accommodation an analysis of the factors that influence travelers' adoption of information from online reviews', Journal of Travel Research, Vol. 53, No. 1, pp.44-57.

Gangadharbatla, H., Hopp, T. and Sheehan, K. (2012) 'Changing user motivations for social networking site usage: implications for internet advertisers', International Journal of Internet Marketing and Advertising, Vol. 7, No. 2, pp.120-135.

Godes, D. and Mayzlin, D. (2004) 'Using online conversations to study word-of-mouth communication', Marketing Science, Vol. 23, No. 4, pp.545-560.

Goh, K., Heng, C. and Lin, Z. (2013) 'Social media brand community and consumer behavior: quantifying the relative impact of user-and marketer-generated content', Information Systems Research, Vol. 24, No. 1, pp.88-107.

Grewal, D., Krishnan, R., Baker, J. and Borin, N. (1998) 'The effect of store name, brand name and price discounts on consumers' evaluations and purchase intentions', Journal of Retailing, Vol. 74, No. 3, pp.331-352.

Gruen, T.W., Osmonbekov, T. and Czaplewski, A.J. (2006) 'eWOM: the impact of customer-tocustomer online know-how exchange on customer value and loyalty', Journal of Business Research, Vol. 59, No. 4, pp.449-456.

Haywood, K.M. (1989) 'Managing word of mouth communications', Journal of Services Marketing, Vol. 3, No. 2, pp.55-67.

Hennig-Thurau, T., Gwinner, K.P., Walsh, G. and Gremler, D.D. (2004) 'Electronic word-ofmouth via consumer-opinion platforms: what motivates consumers to articulate themselves on the internet?'-Journal of Interactive Marketing, Vol. 18, No. 1, pp.38-52.

Herr, P.M., Kardes, F.R. and Kim, J. (1991) 'Effects of word-of-mouth and product-attribute information on persuasion: an accessibility-diagnosticity perspective', Journal of Consumer Research, Vol. 17, No. 4, pp.454-462.

Hoffman, D.L. and Fodor, M. (2010) 'Can you measure the ROI of your social media marketing?', Sloan Management Review, Vol. 52, No. 1, pp.41-49.

Hosmer Jr., D.W., Lemeshow, S. and Sturdivant, R.X. (2013) Applied Logistic Regression, 3rd ed., John Wiley \& Sons, New Jersey.

Huang, L. (2010) 'Social contagion effects in experiential information exchange on bulletin board systems', Journal of Marketing Management, Vol. 26, Nos. 3/4, pp.197-212.

Huang, M., Cai, F., Tsang, A.S. and Zhou, N. (2011) 'Making your online voice loud: the critical role of WOM information', European Journal of Marketing, Vol. 45, Nos. 7/8, pp.1277-1297.

Hung, K.H. and Li, S.Y. (2007) 'The influence of eWOM on virtual consumer communities: social capital, consumer learning, and behavioral outcomes', Journal of Advertising Research, Vol. 47, No. 4, pp.485-495.

Jansen, B.J., Zhang, M., Sobel, K. and Chowdury, A. (2009) 'Twitter power: Tweets as electronic word of mouth', Journal of the American Society for Information Science and Technology, Vol. 60, No. 11, pp.2169-2188.

Kim, S. and Choi, S. M. (2012) 'Credibility cues in online shopping: an examination of corporate credibility, retailer reputation, and product review credibility', International Journal of Internet Marketing and Advertising, Vol. 7, No. 3, pp.217-236.

King, R.A., Racherla, P. and Bush, V.D. (2014) 'What we know and don't know about online word-of-mouth: a review and synthesis of the literature', Journal of Interactive Marketing, Vol. 28, No. 3, pp.167-183.

Kolbe, R.H. and Burnett, M.S. (1991) 'Content-analysis research: an examination of applications with directives for improving research reliability and objectivity', Journal of Consumer Research, Vol. 18, No. 2, pp.243-250. 
Kotler, P. and Armstrong, G. (2013) Principles of Marketing, 15th global ed., Pearson, Kendallville.

Kozinets, R., Wojnicki, A.C., Wilner, S.J. and De Valck, K. (2010) 'Networked narratives: understanding word-of-mouth marketing in online communities', Journal of Marketing, March, Vol. 74, No. 2, pp.71-89.

Kumar, N. and Benbasat, I. (2006) 'Research note: the influence of recommendations and consumer reviews on evaluations of websites', Information Systems Research, Vol. 17, No. 4, pp.425-439.

Lee, M. and Youn, S. (2009) 'Electronic word of mouth (eWOM) how eWOM platforms influence consumer product judgement', International Journal of Advertising, Vol. 28, No. 3, pp.473-499.

Liang, S.W., Ekinci, Y., Occhiocupo, N. and Whyatt, G. (2013) 'Antecedents of travellers' electronic word-of-mouth communication', Journal of Marketing Management, Vol. 29, Nos. 5/6, pp.584-606.

Lim, Y., Chung, Y. and Weaver, P.A. (2012) 'The impact of social media on destination branding consumer-generated videos versus destination marketer-generated videos', Journal of Vacation Marketing, Vol. 18, No. 3, pp.197-206.

Lin, Z. and Goh, K.Y. (2011) 'The economic value of social media user-and marketer- generated content: a network perspective on content sentiment and content information', Proceedings of 32nd International Conference on Information Systems (ICIS).

Litvin, S.W., Goldsmith, R.E. and Pan, B. (2008) 'Electronic word-of-mouth in hospitality and tourism management', Tourism Management, Vol. 29, No. 3, pp.458-468.

Liu, Y. (2006) 'Word of mouth for movies: its dynamics and impact on box office revenue', Journal of Marketing, Vol. 70, No. 3, pp.74-89.

Lovett, M.J., Peres, R. and Shachar, R. (2013) 'On brands and word of mouth', Journal of Marketing Research, Vol. 50, No. 4, pp.427-444.

MacKenzie, S.B. (1986) 'The role of attention in mediating the effect of advertising on attribute importance', Journal of Consumer Research, Vol. 13, No. 2, pp.174-195.

Michaelidou, N., Siamagka, N.T. and Christodoulides, G. (2011) 'Usage, barriers and measurement of social media marketing: an exploratory investigation of small and medium B2B brands', Industrial Marketing Management, Vol. 40, No. 7, pp.1153-1159.

Nusair, K., Jin Yoon, H., Naipaul, S. and Parsa, H. (2010) 'Effect of price discount frames and levels on consumers' perceptions in low-end service industries', International Journal of Contemporary Hospitality Management, Vol. 22, No. 6, pp.814-835.

Okazaki, S. (2009) 'Social influence model and electronic word of mouth: PC versus mobile internet', International Journal of Advertising, Vol. 28, No. 3, pp.439-472.

Park, D., Lee, J. and Han, I. (2007) 'The effect of on-line consumer reviews on consumer purchasing intention: the moderating role of involvement', International Journal of Electronic Commerce, Vol. 11, No. 4, pp.125-148.

Peters, K. and Kashima, Y. (2007) 'From social talk to social action: shaping the social triad with emotion sharing', Journal of Personality and Social Psychology, Vol. 93, No. 5, p.780.

Presi, C., Saridakis, C. and Hartmans, S. (2014) 'User-generated content behaviour of the dissatisfied service customer', European Journal of Marketing, Vol. 48, Nos. 9/10, pp.1600-1625.

Qi, J., Qu, Q., Tan, Y. and Mu, J. (2014) 'Modeling MGC strategies under extreme negative UGC', Journal of Electronic Commerce Research, Vol. 15, No. 3, pp.150-161.

Reichelt, J., Sievert, J. and Jacob, F. (2014) 'How credibility affects eWOM reading: the influences of expertise, trustworthiness, and similarity on utilitarian and social functions', Journal of Marketing Communications, Vol. 20, Nos. 1/2, pp.65-81.

Rogers, S. (2014) What Fuels a Tweet's Engagement? [online] https://blog.twitter.com/2014/whatfuels-a-tweets-engagement (accessed 16 April 2015). 
Roznowski, J.L. (2003) 'A content analysis of mass media stories surrounding the consumer privacy issue 1990-2001', Journal of Interactive Marketing, Vol. 17, No. 2, pp.52-69.

Sakaki, T., Okazaki, M. and Matsuo, Y. (2010) 'Earthquake shakes Twitter users: real-time event detection by social sensors', Proceedings of the 19th International Conference on World Wide Web, ACM, pp.851-860.

Schindler, R.M. and Bickart, B. (2005) 'Published word of mouth: referable, consumer-generated information on the internet', Haugtvedt, C.P., Machleit, K.A. and Yalch, R. (Eds.): Online Consumer Psychology: Understanding and Influencing Consumer Behavior in the Virtual World, Lawrence Erlbaum Associates, Inc, New Jersey, pp.35-61.

Scholz, M., Dorner, V., Landherr, A. and Probst, F. (2013) 'Awareness, interest, and purchase: the effects of user-and marketer-generated content on purchase decision processes', 34th International Conference on Information Systems, pp.1-17.

Sigala, M., Christou, E. and Gretzel, U. (Eds.) (2012) Social Media in Travel, Tourism and Hospitality: Theory, Practice and Cases, Ashgate Publishing, Ltd., Great Britain.

Smith, A.N., Fischer, E. and Yongjian, C. (2012) 'How does brand-related user-generated content differ across YouTube, Facebook, and Twitter?', Journal of Interactive Marketing, Vol. 26, No. 2, pp.102-113.

Suh, B., Hong, L., Pirolli, P. and Chi, E.H. (2010) 'Want to be retweeted? Large scale analytics on factors impacting retweet in Twitter network', Social Computing (Socialcom) Second International Conference, IEEE, pp.177-184.

Swani, K., Brown, B.P. and Milne, G.R. (2014) 'Should tweets differ for B2B and B2C? An analysis of Fortune 500 companies' Twitter communications', Industrial Marketing Management, Vol. 43, No. 5, pp.873-881.

Tsimonis, G. and Dimitriadis, S. (2014) 'Brand strategies in social media', Marketing Intelligence \& Planning, Vol. 32, No. 3, pp.328-344.

Twitter (2015) About Company: Twitter Usage [online] https://about.twitter.com/company (accessed 16 April 2015).

van den Bergh, B.G., Lee, M., Quilliam, E.T. and Hove, T. (2011) 'The multidimensional nature and brand impact of user-generated ad parodies in social media', International Journal of Advertising, Vol. 30, No. 1, pp.103-131.

Wang, X., Yu, C. and Wei, Y. (2012) 'Social media peer communication and impacts on purchase intentions: a consumer socialization framework', Journal of Interactive Marketing, Vol. 26, No. 4, pp.198-208.

Wolny, J. and Mueller, C. (2013) 'Analysis of fashion consumers' motives to engage in electronic word-of-mouth communication through social media platforms', Journal of Marketing Management, Vol. 29, Nos. 5/6, pp.562-583.

Yang, F.X. (2013a) 'Effects of restaurant satisfaction and knowledge sharing motivation on eWOM intentions: the moderating role of technology acceptance factors', Journal of Hospitality \& Tourism Research, doi: 10.1177/1096348013515918, ahead-of-print.

Yang, H. (2013b) 'A cross-cultural study of market mavenism in social media: exploring young American and Chinese consumers' viral marketing attitudes, eWOM motives and behaviour', International Journal of Internet Marketing and Advertising, Vol. 8, No. 2, pp.102-124.

Yayl, A. and Bayram, M. (2012) 'E-WOM: the effects of online consumer reviews on purchasing decisions', International Journal of Internet Marketing and Advertising, Vol. 7, No. 1, pp.51-64.

Yen, H.R., Hsu, S.H. and Huang, C. (2011) 'Good soldiers on the web: understanding the drivers of participation in online communities of consumption', International Journal of Electronic Commerce, Vol. 15, No. 4, pp.89-120.

Zadeh, A.H. and Sharda, R. (2014) 'Modeling brand post popularity dynamics in online social networks', Decision Support Systems, Vol. 65, pp.59-68.

Zarrella, D. (2009) Science of Retweets [online] http://danzarrella.com/science-of-retweets.pdf (accessed 16 April 2015). 